\title{
Dyskusja panelowa: Kierunki i priorytety promocji zdrowia ogólnie i w odniesieniu do osób starszych szczeyólnie
}

\section{Wprowadzenie}

Przed systemem ochrony zdrowia stoi kilka wielkich wyzwań. Poza starzeniem się populacji, które było przedmiotem konferencyjnej debaty w pierwszej części, mamy także do czynienia z ograniczeniami na rynku pracy zawodów medycznych i okołomedycznych. Niska skłonność do podejmowania kształcenia i pracy lekarza, pielęgniarki czy ratownika jest zjawiskiem uniwersalnym. We współczesnym świecie (inaczej niż jeszcze pół wieku temu) dobre wynagrodzenia i prestiż można także uzyskać w innych sektorach gospodarki i mniejszym kosztem osiągania wysokich kwalifikacji. A wyjątkowa misja pracy w usługach zdrowotnych nie jest wystarczająca do zapewnienia odpowiedniej podaży kadr medycznych.

Kraje zamożniejsze, z lepiej zorganizowanymi systemami zdrowotnymi, korzystają z przepływów migracyjnych jako tak zwane kraje przyjmujące. Selekcjonują i wzmacniają dopływ kadr medycznych. Kraje biedniejsze - wysyłające - tym bardziej na tym tracą.

W Unii Europejskiej polityka migracji pracowniczych jest obecnie tematem gorącym i będzie przedmiotem dalszych regulacji, zwiększających zapewne równoważenie rynków pracy w różnych ich segmentach. Niezależnie od niej podejmowane są na szczeblach krajowych działania łagodzące deficyty kadr, a szczególnie w zawodach medycznych. Jedną $z$ dróg jest rozwój kształcenia specjalistów zdrowia publicznego i promocji zdrowia ukierunkowanych na prewencję, przede wszystkim pierwotną, aby łagodzić popyt na usługi lecznicze. Wszędzie w Europie powstały kierunki kształcenia w tym zakresie. Nie wszędzie jednak powstały miejsca pracy dla tej nowej grupy zawodów, które wzmacniają system ochrony zdrowia oraz zapewniają dbałość o zdrowie populacji.

Polska należy do krajów, w których już na początku lat 90. XX wieku podjęto kształcenie w dziedzinie zdrowia publicznego, zarówno na poziomie studiów podstawowych, jak i kształcenia podyplomowego, chociaż nie zawsze z akcentem na promocję zdrowia. Nie wskazano natomiast dla absolwentów tych kierunków właściwych miejsc pracy. Kształcenie w zakresie zdrowia publicznego prowadzone jest równolegle; $\mathrm{z}$ jednej strony jako podstawowy kierunek studiów (kierunek samodzielny lub na wydziałach nauk o zdrowiu), a z drugiej - jako specjalizacja medyczna dla absolwentów studiów medycznych. Z punktu widzenia problemów ich zatrudnienia odpowiednio do potrzeb systemu ochrony zdrowia nie są to rozwiązania optymalne. Medycy raczej nie podejmują aktywności w zakresie promocji zdrowia (nie są w stanie wobec wzrastającej skali potrzeb leczniczych), a absolwenci zdrowia publicznego obejmują przeróżne stanowiska albo niezwiązane $\mathrm{z}$ ochroną zdrowia, albo organizacyjne, w małym stopniu wzmacniające promocję zdrowia.

Wobec tej sytuacji stoimy w Polsce przed pilną regulacją prawną w zakresie medycznego i okołomedycznego rynku pracy, a przede wszystkim wskazania miejsc pracy (stanowisk) dla zawodów z kompetencjami w realizacji funkcji promocji zdrowia.

W niektórych krajach europejskich (np. w Holandii) wśród stanowisk wskazanych dla specjalistów zdrowia publicznego istnieje stanowisko tak zwanego konsultanta promocji zdrowia: w podstawowej opiece zdrowotnej, administracji lokalnej, w zakładach pracy, w szkołach, w mediach publicznych. Na te stanowiska zatrudniani są wykształceni absolwenci kierunków zdrowia publicznego i/lub odpowiednich studiów podyplomowych. To gwarantuje profesjonalizm działań w zakresie promocji zdrowia i prewencji chorób typowych dla różnych grup ludności (w przypadku osób starszych są to przede wszystkim choroby przewlekłe).

W związku z postawionym problemem spróbujmy podyskutować, odpowiadając sobie na następujące pytania.

1. Jakie podmioty/organizacje/instytucje powinny realizować w naszym kraju promocję zdrowia ogólnie i adresowaną do osób starszych szczególnie?

2. Czy potrzebna jest w Polsce zmiana systemu kształcenia $\mathrm{w}$ zakresie zdrowia publicznego w celu profe- 
sjonalizacji promocji zdrowia i prewencji pierwotnej, adresowanej do różnych grup populacyjnych? Czy raczej potrzebne są regulacje dotyczące rynku pracy - wskazanie stanowisk do zatrudniania odpowiednich grup absolwentów. A może potrzebne jest zdefiniowanie zawodu promotora zdrowia; tak jest w klasyfikacjach zawodów Międzynarodowej Organizacji Pracy oraz w niektórych krajach, na przykład Nowej Zelandii i Australii.

3. Czy w ramach wykonywanych zawodów:

- lekarza POZ;

- pielęgniarki;

- fizjoterapeuty, rehabilitanta;

- dietetyka;

- pracownika socjalnego;

- lekarza medycyny pracy;

- jest miejsce „dla” realizacji funkcji promocji zdrowia i prewencji pierwotnej? Jakie warunki byłyby potrzebne, aby to było realne?

\section{Moderator: Tomasz Zdrojewski}

TOMASZ ZDROJEWSKI: Po wykładzie prof. Tomasza Grodzickiego i wskazaniu niektórych dobrych praktyk promocji zdrowia przez dr Alicję Domagałę, sądzę, że dobrym dopełnieniem i zarazem podsumowaniem tego, co wysłuchaliśmy i obejrzeliśmy, będzie praktyczny panel, do którego chciałbym zaprosić: prof. Tomasza Kostkę - konsultanta krajowego w dziedzinie geriatrii, Marię Kózkę, konsultanta krajowego w dziedzinie pielęgniarstwa, prof. Jacka Postupolskiego, miejscowego eksperta (NIZP-PZH) do spraw żywności, minister dr Joannę Staręgę-Piasek - pioniera ustawodawstwa pomocy społecznej w Polsce, prof. Adama Windaka, reprezentującego lekarzy rodzinnych oraz przedstawiciela samorządów - Marka Wójcika. Dziękuję, że Państwo przyjęli zaproszenie organizatorów konferencji i są gotowi do debaty. Wcześniej wysłaliśmy Państwu list zawierający problem i kilka pytań, ale tutaj chciałbym ze swej strony dodać dwa pytania ogólniejsze.

Po pierwsze: Jak Państwo uważacie, czy bardziej potrzebne są zmiany w systemie kształcenia medycznego i okołomedycznego czy zmiany w ustawie o zdrowiu publicznym?

Po drugie: Gdyby ktoś z Państwa został ministrem zdrowia i na konferencji prasowej został zapytany o priorytety zdrowia publicznego i promocji zdrowia, to jakie działania wskazałby i jak to uzasadnił?

ADAM WINDAK: Choć nie dotarł do mnie wspomniany list, to moja wypowiedź będzie nieco spontaniczna, choć nie ukrywam, że trochę myślałem o dzisiejszym wystąpieniu. Zastanawiałem się, co też Państwu mogę powiedzieć i pomyślałem sobie, że powiem o problemie promocji zdrowia z perspektywy lekarza rodzinnego, jako że jestem praktykującym lekarzem rodzinnym. Prowadzę jedną z nielicznych praktyk lekarza rodzinnego w centrum Krakowa. Nie będę mówił o tym, że lekarzy rodzinnych brakuje, a ci, którzy pracują, są coraz starsi (sam wchodzę w wiek, który jest przedmiotem zainte- resowania tej konferencji), że brakuje pielęgniarek, ponieważ Państwo to wiecie i byłoby to pewnie trywialne. Zadania, które mimo braku środków i niedostatków systemowych podejmujemy w ramach zespołu podstawowej opieki zdrowotnej (także lekarz, pielęgniarka samodzielnie) i powinniśmy je rozwijać, to zindywidualizowane podejście do pacjenta. Pacjenci przychodzą $\mathrm{z}$ bardzo różnymi problemami i w bardzo różnym wieku, co wymaga szerokich kompetencji medycznych oraz wyczulenia na odmienne sprawy każdego z nich.

Prof. Tomasz Grodzicki przedstawił tutaj taki slajd, który wskazywał kilka elementów zdrowego starzenia, poświęcając uwagę głównie chorobom przewlekłym. Słusznie twierdził, że na zapobieganie im w okresie starości jest już za późno. Ja jednak uważam, że w starszym wieku mniej ważne jest, na jakie choroby przewlekłe cierpią pacjenci. Aby to zilustrować, przypomnę takie klasyczne badanie włoskie, w którym poproszono 300 lekarzy rodzinnych o wybranie 10 swoich pacjentów w starszym wieku i wskazanie ich najważniejszych problemów zdrowotnych. Następnie zapytano tych pacjentów, co stanowi dla nich najważniejszy problem zdrowotny. Lekarze wskazali oczywiście, tak jak widzieliśmy na jednym ze slajdów prof. Grodzickiego: nadciśnienie tętnicze, cukrzycę, astmę i inne schorzenia. Natomiast sami pacjenci powiedzieli, że dla nich najważniejsze są problemy z zaburzeniami widzenia, z zaburzeniami słuchu, z brakiem samodzielności i ograniczeniami w poruszaniu się, i to tak naprawdę są problemy starszego pacjenta. Starsi pacjenci są różni i różne narzędzia powinniśmy wykorzystywać w podejmowanych wobec nich działaniach.

Jak powiedziałem, moja praktyka w Krakowie jest jedną z ostatnich; parę dni temu zamknięto sąsiednią praktykę z powodu wysokiego czynszu, którego nie można było pokryć. Nota bene w centrum Krakowa czynsze są dramatycznie wysokie. W spadku po tej praktyce otrzymaliśmy kilkuset nowych pacjentów, których ja do dzisiaj poznaję. W ostatnim tygodniu przyszły dwie osoby w starszym wieku. Jedna z tych osób to 62-letni bezrobotny, były urzędnik magistratu, który nie pracuje od kilkunastu lat. Żywi się skromnie w kuchni Brata Alberta i mówi, że czasami zje coś lepszego, jeżeli kuzyn go wspomoże finansowo. Przyszedł z prośbą o wystawienie wniosku do wojewódzkiego zespołu orzekania o niepełnosprawności, bo chciałby coś więcej uzyskać, a takie orzeczenie będzie mu pomocne. Druga osoba to siedemdziesięcioparoletnia, aktywna zawodowo pani profesor, która w porównaniu ze wspomnianym wcześniej pacjentem miała znacznie więcej różnych schorzeń, ale nie zamierzała rezygnować z pracy. Z nich dwojga o wiele zdrowszy w sensie fizycznym był bezrobotny urzędnik. Przytoczony przykład pokazuje, że zdrowo starzeją się nie tylko ci, którzy mają mniej schorzeń. Decydująca jest aktywność. Tych dwoje potrzebowało odmiennych interwencji. W promocji zdrowia ukierunkowanej na starsze pokolenie powinniśmy wykorzystywać różne narzędzia wobec różnych pacjentów. Dobre programy profilaktyczne budzą nadzieję, choć na razie jest ich za mało. Być może, zapowiadane pojawienie się $\mathrm{w}$ systemie ochrony zdrowia promotorów i edukatorów zdrowia odmieni tę sytuację. 
MAREK WÓJCIK: Istotnie, należy rozróżniać różne etapy starzenia się (tak zwany III i IV wiek). Interwencje medyczne, które będą kierowane do starszych pacjentów, muszą być inne w zależności od „fazy” starości, związanej z wiekiem biologicznym, ale także ze względu na różne zachowania i postawy starszych ludzi.

Korzystając z okazji, wrócę do problemu dobrych praktyk. Zachęcam do zajrzenia na stronę www.dobrepraktyki.pl. Przedstawiono tam kilkadziesiąt praktyk samorządowych także kierowanych do osób starszych w celu ich aktywizacji i podtrzymania zdrowia.

Będę tu promował działania samorządów terytorialnych i zarazem ich bronił. Gdyby nie samorządy, to mielibyśmy dramatyczną sytuację w zakresie wspierania osób starszych i promocji zdrowia adresowanej do nich. Samorządom jednak w tych działaniach trzeba pomóc. W prezentowanym podręczniku ${ }^{1}$ Państwo zwracacie uwagę na rolę lokalnego koordynatora promocji zdrowia. To jest bardzo dobry pomysł, ale nie sprawdzi się, jeżeli ten promotor/koordynator zdrowia nie będzie miał narzędzi prawnych i finansowych. Mamy w życiu publicznym wiele takich przypadków, kiedy wskazując jakieś zadanie, nie wyznacza się mu narzędzi realizacji. Wtedy nie osiągniemy założonych i pożądanych rezultatów.

Uważam, drodzy Państwo, że dyskutując na temat ustawy o zdrowiu publicznym, musimy wskazać „dla” jej realizacji odpowiednie środki. Na zdrowie publiczne należy przeznaczyć kwotę rzędu 4 miliardów zł. Tyle, moim zdaniem, co najmniej potrzeba. Ponadto uważam, że powinniśmy być radykalni w motywowaniu do zdrowego stylu życia. Należy nagradzać tych, którzy dbają o swoje zdrowie i karać tych, którzy o zdrowie nie dbają. $\mathrm{W}$ praktyce bywa odwrotnie. Ci, którzy o zdrowie nie dbają, prowadząc ryzykowny zdrowotnie tryb życia, więcej chorują i więcej nas kosztują.

Koordynator promocji zdrowia i edukator zdrowotny będą mieli szansę na skuteczne działanie, gdy ich narzędzia będą opierały się na dwóch mechanizmach. Pierwszy to dotarcie do świadomości samych zainteresowanych. Przypomina mi się piosenka Wojciecha Młynarskiego. Mówi ona o tym, że jak ktoś nie odróżnia Szymborskiej od Dąbrowskiej albo Miłosza od Norwida, to „,wychodzi mu to na twarz”. Młodzież mówi o takich ludziach „,nieskalani intelektem”. Młynarski śpiewał w tej piosence, że można zmienić tę buźkę i są na to dwa lekarstwa: myślenie, czytanie i tak przez trzy pokolenia. Mówię o tym dlatego, że także budowanie świadomości dbania o zdrowie jest długotrwałym procesem. Tymczasem o wiele szybszy, chociaż bolesny, będzie drugi mechanizm - motywacja ekonomiczna. Ludzie powinni poczuć, że opłaci im się dbać o zdrowie, a na to istnieją różne pomysły. Jeżeli jednak nie będziemy umiejętnie wprowadzać motywacji ekonomicznej w życie, to nie będziemy skuteczni, a przy tym skompromitujemy ten mechanizm.

Ostatni punkt mojej wypowiedzi dotyczy pytania, co bym zrobił, będąc ministrem zdrowia. Zachęcam Państwa do zapoznania się z fantastycznym raportem, który zrobiono na zlecenie NFZ w związku z debatą nad ustawą o podstawowej opiece zdrowotnej. W ustawie o POZ przewidziano funkcję koordynatora zespołu POZ.
Zapytano pacjentów, co na ten temat sądzą. Opinie pacjentów były entuzjastyczne. Jeżeli znajdzie się osoba, która będzie dobrze poinformowana, będzie ustalała terminy, koordynowała ich wizyty, znała ich schorzeniach i na przykład próbowała odpowiedzieć, jak wyglądają wyniki ich badań, to oni będą bardzo chętnie z usług takiej osoby korzystać. Nawiążę w tym także do ekonomii. Jeżeli chcemy mieć koordynatorów promocji zdrowia, a to jest bardzo dobra propozycja, to musimy uwzględnić prawo podaży i popytu. Administracyjne ustalenie nowej funkcji nie rozwiąże problemu. Na działania promocji zdrowia musi być popyt. Wtedy potrzebni będą koordynatorzy promocji i edukacji zdrowia. A popyt na usługi związane z promocją zdrowia będzie znacząco rósł.

TOMASZ ZDROJEWSKI: Poruszył Pan cenne wątki, które mogą być podstawą do osobnej dyskusji. Zgadzam się z tym, co Pan powiedział o bodźcach ekonomicznych. Teraz jeśli Pan pozwoli, poproszę o przekazanie mikrofonu Pani minister Joannie Starędze-Piasek. Zwracam się z pytaniem do Pani, odwołując się do Pani doświadczenia, jakie oczekiwania wobec naszego tematu miała Pani wiele lat temu, a jakie recepty dawałaby Pani dzisiaj.

JOANNA STARĘGA-PIASEK: Odpowiadając na pytania zadane w liście, chciałam powiedzieć o dwóch sprawach ogólnie. Po pierwsze, jesteśmy bardzo dobrzy w teorii i właściwie o promocji zdrowia, o zdrowiu publicznym, o potrzebnych instrumentach, które są niezbędne, możemy teoretycznie dużo powiedzieć. I ta dzisiejsza konferencja, która jest naprawdę bardzo ciekawa, o tym świadczy. Po drugie, jesteśmy natomiast słabi w praktyce. I tu chciałabym postawić pewien dwukropek i powiedzieć, że chcę tutaj zarekomendować pracowników socjalnych jako potencjalnych promotorów zdrowia. To jest dobra grupa zawodowa, już nowocześnie wykształcona i odpowiedzialna za trudne sprawy socjalne. Jest to także wdzięczna grupa zawodowa i to nie dlatego, że pracownikami socjalnymi są w 90\% kobiety, ale wdzięczna w innym rozumieniu, chętna do współpracy (na przykład z lekarzem rodzinnym), godna bycia emisariuszem zaleceń medycznych w praktyce promocji zdrowia.

W tym miejscu chcę odwołać się do innej ustawy ustawy o pomocy społecznej. Ustawa ta w potocznym rozumieniu dotyczy przede wszystkim ubóstwa, które jest głównym powodem sięgania po wsparcie i udzielania go. Równie dobrze mogłabym udowodnić, że zły stan zdrowia jest bardzo ważnym czynnikiem dysfunkcji danej osoby i może być tej dysfunkcji przyczyną albo skutkiem. Chcę podkreślić, że pracownicy socjalni w ramach wykonywania swojego zawodu nie tylko postrzegają swoich podopiecznych indywidualnie, lecz widzą też rodzinę oraz otoczenie, w którym dana osoba żyje. Wszystko jedno, czy jest to starsza osoba, zdrowa czy chora. Ani razu nie padło jeszcze słowo rodzina jako najbliższy kontekst społeczny, w którym widzimy rezultaty działania promocji zdrowia i w którym teoria może być nieźle praktykowana i weryfikowana. Rodzina to jest wzajemna kontrola, a zarazem wsparcie w różnych sytuacjach. Chcę 
powiedzieć, że pracownik socjalny opiekujący się osobą chorą i starszą w jej otoczeniu (rodzina, grupa sąsiedzka, sieć społeczna) również wykonuje zadania koordynatora promocji zdrowia, czyli te, o których jest tutaj mowa.

JACEK POSTUPOLSKI: Zgadzam się z tym, że edukację zdrowotną trzeba zaczynać co najmniej pokolenie wcześniej. W osiąganiu zdrowego stylu życia bardzo ważny jest sposób odżywiania się. Ciągle zmieniają się zwyczaje żywieniowe, a reklamy w telewizji mają ogromny wpływ na osoby starsze. Opierając się na reklamach, można by sądzić, że nie trzeba zmieniać stylu życia, odpowiedzialność za styl życia zdejmują z nas dostępne na rynku preparaty - suplementy diety. Działania promocji zdrowia nie mogą być realizowane bez konsultacji z dietetykami - to bardzo ważne ogniwo w promocji zdrowia i edukacji zdrowotnej dla wszystkich, a dla osób starszych szczególnie.

MARIA KÓZKA: Dziękuję bardzo za zaproszenie i postaram się odpowiedzieć na zadane pytania konkretnie, w odniesieniu do wskazanych zawodów.

Od 1999 roku nastapiła w Polsce zmiana w zakresie kształcenia pielęgniarek i położnych. Mamy programy dostosowane do wymagań europejskich, w których mocno akcentowana jest promocja zdrowia, edukacja zdrowotna i opieka. Dostrzegamy jednak, że nasi absolwenci nie są skuteczni w osiąganiu celów programów w zakresie promocji i edukacji zdrowotnej. Programy te są realizowane przez różne instytucje, zarówno przez uczelnie, jak i samorządy terytorialne. Finansowane są z dotacji europejskich, a także z krajowych. Nie są jednak oceniane $\mathrm{z}$ punktu widzenia ich skuteczności. $Z$ tego powodu chcemy zmodyfikować program studiów II stopnia, żeby przygotować absolwentów do osiągania większej skuteczności, dając im odpowiednie instrumenty. Obecnie toczy się o tym dyskusja w ramach powołanego zespołu opracowania strategii rozwoju na rzecz pielęgniarstwa i położnictwa. Więcej informacji nie mogę w tej chwili ujawniać, ponieważ prace jeszcze nie są zakończone Planujemy zadania edukacji zdrowotnej przekazać magistrom pielęgniarstwa oraz zabiegać o kontraktowanie tych świadczeń.

Ważną kwestią są również regulacje prawne, które są pomocne w określeniu zadań dla pielęgniarek, głównie w edukacji i w prewencji. Myślę, że tutaj zwłaszcza w POZ-ach jest duże pole do działania, w tym włączenie różnych specjalistów, na przykład pracowników socjalnych czy opiekunów medycznych. Popatrzmy na domy spokojnej starości, miejsce zamieszkania osób najstarszych. W tych placówkach tylko pielęgniarka wykonuje usługi instrumentalne, a nie ma kontraktu z NFZ w zakresie działań promocyjno-edukacyjnych, to zaś mogłoby stanowić pole do działania dla różnych osób.

A teraz chciałabym odnieść się do pracy absolwentów zdrowia publicznego. Analiza losów zawodowych absolwentów kierunku zdrowie publiczne wskazuje, że $60 \%$ nie pracuje w swoim zawodzie. W związku z tym warto się zastanowić nad wykorzystaniem potencjału tych ludzi. Po pierwsze, należałoby dokonać modyfikacji programu i profilu kształcenia. Profil studiów pierwszego stopnia powinien być praktyczny, a nie ogólnoakademicki. Po drugie, przekazać uprawnienia w zakresie promocji zdrowia absolwentom zdrowia publicznego, a nie tworzyć dodatkowych zawodów (np. koordynatorów i edukatorów zdrowia). Wydaje mi się, że taka dyskusja powinna być prowadzona w szerszym gronie. Po latach funkcjonowania kierunku zdrowie publiczne warto się zastanowić nad zmianami i lepszym wykorzystaniem absolwentów w systemie ochrony zdrowia.

TOMASZ ZDROJEWSKI: Panie profesorze Tomaszu Kostka, zostaje Pan ministrem zdrowia i co teraz Pan zrobi, co Pan zrobi w pierwszych dwóch, trzech działaniach?

TOMASZ KOSTKA: Przede wszystkim chciałbym podziękować za zaproszenie Pani profesor, Panom profesorom. Uważam, że jest to niezwykle ważna konferencja. Nie ulega wątpliwości, że w warunkach starzejącego się społeczeństwa utrzymanie seniorów w sprawności funkcjonalnej to jest prawdopodobnie największe wyzwanie dla zdrowia publicznego na najbliższe lata.

Jako minister przede wszystkim odciąłbym decydentów od osobnej ścieżki dostępu do szpitali. Wtedy odczulibyśmy, jak ten system działa naprawdę.

My (tutaj jest spora grupa geriatrów na tej sali) na co dzień widzimy tych starszych i schorowanych ludzi, którzy $\mathrm{z}$ ogromnym trudem są w stanie dotrzeć do tej jedynej poradni na ogromnym obszarze, gdzie staramy się im pomóc w kilku czy kilkunastu chorobach naraz. I dopóki świadomość tego braku wobec narastającej potrzeby starszych ludzi nie dotrze do decydentów, to niewiele się zmieni. Myślę także, że ta świadomość powinna być większa także u nas samych. W praktyce mamy inne możliwości niż dziewięćdziesiąt parę procent społeczeństwa. Jeżeli my mamy problem ze zdrowiem, to korzystamy z koleżeńskiej przysługi kolegów profesorów czy dyrektorów szpitali i sobie radzimy.

Jako geriatrzy zajmujemy się najbardziej schorowaną, najstarszą częścią społeczeństwa. Z punktu widzenia zdrowia publicznego geriatria czy gerontologia prewencyjna są tutaj absolutnie podstawą. Czyli chodzi o budowanie potencjału biologicznego, identyfikację czynników ryzyka, rozbudowany zakres działań, o których była tu mowa, a które mają za zadanie takie spowolnienie spadku sprawności funkcjonalnej wraz z wiekiem, żeby to wejście pod próg niepełnosprawności odbywało się jak najpóźniej, czyli krótko mówiąc: kompresja okresu niepetnosprawności. I żeby ten okres niepełnosprawności nastąpił jak najpóźniej. Jak mówi jedno z istotnych haseł geriatrii: chcemy dodać życia do lat, bardziej niż lat do życia. Bardzo często prowokuję studentów w ten sposób. Mówię tak: „Proszę Państwa, macie dwie możliwości: żyjecie 95 lat, ale ostatnie 10 lat spędzacie jako osoby niepełnosprawne w łóżku. Albo żyjecie 90 lat i do końca jesteście osobami sprawnymi i samodzielnymi. Kto z Państwa jest za wersją pierwszą?”. Jak się Państwo domyślacie, wszyscy studenci byli za wersją drugą. Pytam wtedy: „Co Państwo zrobiliście, właśnie świadomie 
skróciliście sobie życie”. Dlatego więcej wysiłku należy kierować na poprawę jakości życia, ale jakości niekoniecznie rozumianej jako wakacje na Bahamach, tylko jako życie bez bólu, bez cierpienia w ostatniej fazie życia. Potrzebna nam jest taka debata i odpowiednie działania. Dlatego ta konferencja - budowanie potencjału starzenia się w zdrowiu ze świadomością, że promocja zdrowia jest tu podstawą - jest bardzo ważna. Absolutnie powinniśmy zrobić wszystko, żeby ten kierunek działań popierać.

TOMASZ ZDROJEWSKI: Bardzo dziękuję. Myślę, że treści zawarte w tej dyskusji panelowej staną się stymulatorem konkretnych działań w kierunku praktycznej promocji zdrowia i edukacji zdrowotnej.

STANISŁAWA GOLINOWSKA - GŁOS POKONFERENCYJNY: Badania prowadzone w ramach projektu „ProHealth 65+" dostarczyły informacji także o tym, w ramach jakich zawodów realizowane są działania promocji zdrowia. W kilku krajach istnieje zawód i stanowisko promotora zdrowia. Przyjrzeliśmy się szczególnie, jak to wygląda u Holendrów, naszych głównych partnerów projektowych. I co ważne, nie tylko do takiego zawodu kształci się młodych ludzi na akademiach medycznych, ale istnieje tam także stanowisko tak zwanego konsulenta promocji zdrowia (tytuł zawodowy oznaczający wysokie kompetencje w danej dziedzinie - nie mylić z konsultantem), który na szczeblu lokalnym koordynuje zadania w dziedzinie promocji zdrowia.

Zawód promotora zdrowia ma natomiast swoje miejsce w klasyfikacji zawodów i specjalności Międzynarodowej Organizacji Pracy. W polskiej wersji tej klasyfikacji, przygotowanej w 2010 roku w ówczesnym Ministerstwie Pracy i Polityki Społecznej, wyróżnia się wśród specjalistów do spraw higieny, bezpieczeństwa pracy i ochrony środowiska zawód promotora zdrowia, którego zadaniem jest prowadzenie działań promujących zdrowie i zdrowy styl życia skierowanych do szerokiej grupy społecznej. Opis tego zawodu dostępny na stronie internetowej (ftp://kwalifikacje.praca.gov.pl/standardy\%20kompetencji\%20zawodowych/18_228202_Promotor_zdrowia.pdf) jest następujący:

„Promotor zdrowia podejmuje działania umożliwiające jednostkom i społeczności krzewienie zdrowego stylu życia i tworzenie warunków sprzyjających zdrowiu. Podstawowym celem jego pracy jest aktywizowanie społeczności lokalnej do działań na rzecz zdrowia, popieranie i rozwijanie postaw prozdrowotnych, rozwijanie wiedzy i umiejętności w promowaniu zdrowia własnego i innych. Wykonuje zadania polegające na: identyfikowaniu zagrożeń zdrowotnych społeczeństwa w regionie; określaniu indywidualnych i społecznych potrzeb zdrowotnych; opracowywaniu, wdrażaniu, realizacji i ewaluacji programów promocji zdrowia związanych z prozdrowotną zmianą zachowań i stylu życia oraz warunków umożliwiających tę zmianę, organizowaniu edukacji zdrowotnej, a także realizowaniu we współpracy z instytucjami, organizacjami państwowymi i społecznymi programów promocji zdrowia. Opracowuje i przekazuje stosownym podmiotom sprawozdania dotyczące zrealizowanych i planowanych programów zdrowotnych".

Istnieje więc podstawa, aby wprowadzić ten zawód, zgodnie z odpowiednią regulacją, do praktyki i utworzyć w Polsce w instytucjach ochrony zdrowia, edukacji, sportu i rekreacji oraz $\mathrm{w}$ instytucjach samorządów terytorialnych stanowiska specjalistów do spraw promocji zdrowia. To też wymaga wypracowania odpowiedniego profilu kształcenia, a przede wszystkim wprowadzenia kierunku promocji zdrowia do studiów nauk o zdrowiu (na przykład na kierunku zdrowie publiczne). Ta dyskusja panelowa, bardzo cenna dla sprawy, potwierdziła zasadność, a nawet konieczność podjęcia odpowiednich działań w celu rozwiązania w Polsce problemu zawodu i stanowisk pracy dla promotorów zdrowia, także pracujących na rzecz osób starszych.

\section{Przypis}

${ }^{1}$ Promocja zdrowia dla osób starszych. Podręcznik dla promotorów zdrowia, S. Golinowska (red. nauk.), Wydawnictwo Naukowe Scholar, Warszawa 2017.

Wypowiedzi spisała i przygotowała do publikacji (po ich autoryzacji): Elżbieta Ryś.

Redakcja: Stanistawa Golinowska

Adres do korespondencji: Stanisława Golinowska, Zakład Ekonomiki Zdrowia i Zabezpieczenia Społecznego, Instytut Zdrowia Publicznego, Wydział Nauk o Zdrowiu, Uniwersytet Jagielloński Collegium Medicum, ul. Grzegórzecka 20,31-531 Kraków, stellag@onet.pl 